\title{
REKAYASA MESIN PENGOLAH LIMBAH PERTANIAN DAN PERKEBUNAN SISTEM ROTARY UNTUK PEMBUATAN PAKAN ALTERNATIF TERNAK ENTOK YANG EKONOMIS
}

\author{
Oleh: \\ Musabbikhah ${ }^{1}$ dan Samsul Bakri \\ 1Prodi Teknik Mesin Sekolah Tinggi Teknologi "Warga” Surakarta \\ 1'moesika12@gmail.com
}

\begin{abstract}
Abstrak
Permasalahan utama Kelompok Tani Harapan Umat (Koptan Harum) yang memiliki usaha pertanian dan peternakan di Gondangrawe adalah proses pengolahan limbah pertanian dan perkebunan untuk pakan ternak entok masih tradisional. Peralatan yang digunakan yaitu alu dan lumpang untuk menumbuk limbah, sedangkan sabit untuk merajang limbah. Dampaknya proses pembuatan pakan alternatif lama, kapasitas terbatas, dan rendahnya mutu pakan ternak. Tujuan Kegiatan Program Kemitraan Masyarakat (PKM) ini adalah rekayasa mesin pengolah limbah pertanian dan perkebunan menggunakan sistem rotary untuk produksi pakan alternatif ternak entok yang ekonomis agar dapat mengurangi biaya pakan pabrik yang semakin melambung. Spesifikasi mesin ini: kapasitas $80 \mathrm{~kg} / \mathrm{jam}$, penggerak Diesel $22 \mathrm{HP}$, pisau baja cold work steel (58-60 hrc), Bahan: besi UNP15, plat eser 15, besi siku, hollow, sistem rotary.

Dengan ketersediaan mesin ini, proses pengolahan pakan ternak cepat, hasil pakan berkualitas, meminimasi biaya pakan ternak sehingga kesejahteraan mitra semakin meningkat. Luaran yang dihasilkan dalam kegiatan PKM adalah 1) Mesin pengolah limbah pertanian dan perkebunan kapasitas $80 \mathrm{~kg} / \mathrm{jam}, 2$ ) Pakan alternatif ternak entok yang ekonomis, 3) Perbaikan proses produksi dan sistem usaha. Berdasarkan hasil aplikasi mesin yang telah diterapkan di Koptan Harum menunjukkan bahwa kapasitas produksi pakan ternak meningkat dari $4 \mathrm{~kg} / \mathrm{jam}$ menjadi $80 \mathrm{~kg} / \mathrm{jam}$. Secara ekonomi, penggunaan pakan alternatif ini dapat menekan biaya pakan dari pabrik sebesar Rp. 7.214.000/100 ekor entok.
\end{abstract}

Kata Kunci: limbah, mesin pengolah limbah, rotary, pakan alternatif.

\begin{abstract}
The main problem of Koptan Harum group which has an agricultural and livestock business in Gondangrawe is that the processing of agricultural and plantation waste for wild duck animal feed is still traditional. The equipment used is a pestle and mortar for pounding the waste, while the sickle is for chopping the waste. The impact is the long process of making alternative feed, limited capacity, and low quality of animal feed.The purpose of the activity is to engineer agricultural and plantation waste processing machines using a rotary system for the production of an economical alternative for a wild duck in order to reduce factory feed costs which are increasingly inflated. Specifications of the machine: capacity 80 kg/hour, Power: Diesel $22 \mathrm{HP}$, cold work steel blade, Material UNP15 iron, eser plate, and rotary system.

With the availability of this machine, the processing of animal feed is fast, quality feed results minimize the cost of animal feed so that the welfare of partners will increase. The outputs produced in PKM activities are 1) agricultural and plantation waste processing machines with a capacity of $80 \mathrm{~kg} / \mathrm{hour}$, 2) economical alternative feed for wild duck, 3) Improvement of production processes and business systems. Based on the results of machine applications that have been implemented in Koptan Harum, it shows that the production capacity of animal feed has increased from $4 \mathrm{~kg} / \mathrm{hour}$ to $80 \mathrm{~kg} / \mathrm{hour}$. Economically, the use of this alternative feed can reduce the cost of feed from the factory by $\mathrm{Rp}$. 7.214.800/100 duck.
\end{abstract}

Keywords: waste, waste processing machines, rotary, alternative feed

\section{PENDAHULUAN}

Kelompok Tani Harapan Umat (Koptan
Harum) yang memiliki usaha bidang
pertanian dan peternakan. Permasalahan yang dihadapi Koptan Harum adalah proses pengolahan limbah pertanian dan perkebunan menjadi pakan tambahan ternak entok yang ekonomis dan bergizi, sebagai pengganti bekatul dan konsentrat. Selama ini 
proses pengolahan limbah masih manual dengan cara ditumbuk dan dirajang menggunakan sabit. Hal ini mengakibatkan proses pembuatan pakan ternak lama, kuantitas terbatas, kualitas pakan ternak rendah seperti disajikan pada Gambar 1.
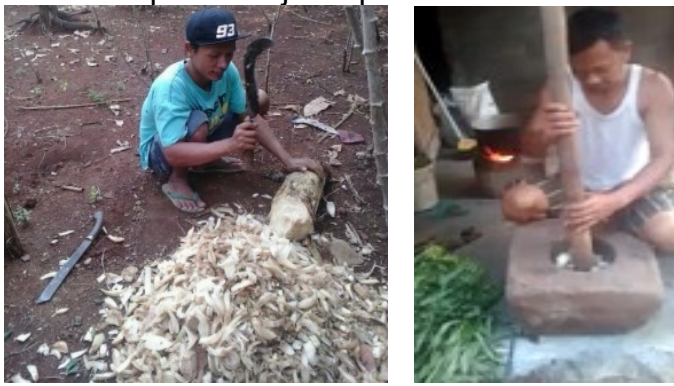

Gambar 1. Pembuatan pakan ternak entok secara tradisional/manual

Berdasarkan Gambar 1 menunjukkan bahwa pembuatan pakan ternak entok secara manual dengan cara ditumbuk dan dirajang menggunakan sabit. sehingga membutuhkan waktu lama, hasil yang diperoleh terbatas, kualitas pakan kurang baik ditinjau dari homogenitas dan tekstur. Selanjutnya, bahan dicampur dengan protein nabati (kangkung dan daun-daunan) serta protein hewani (limbah ikan asin/teri). Pakan yang sudah jadi diberikan kepada ternak entok. Namun karena pakan belum difermentasi, entok kurang lahap untuk menyantap pakan ternak alternatif tersebut seperti disajikan pada Gambar 2.

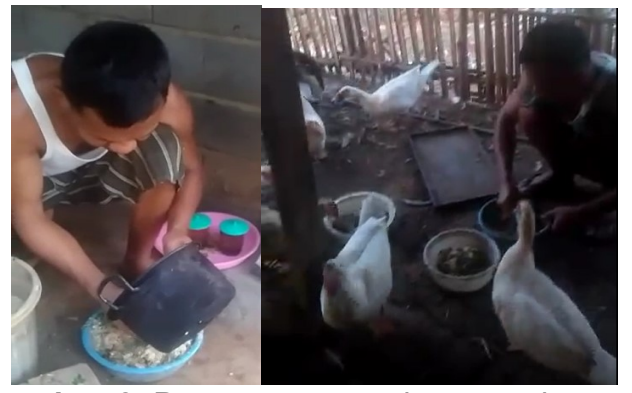

Gambar 2. Pencampuran pakan ternak entok dengan protein nabati dan hewani

Bertitik tolak dari permasalahan ini, maka Tim pengabdi memberikan solusi pada mitra Koptan Harum dalam pembuatan pakan ternak alternatif. Tujuan kegiatan ini meliputi: merekayasa mesin pengolah limbah pertanian dan perkebunan menjadi pakan alternatif ternak entok berkapasitas $80 \mathrm{~kg} / \mathrm{hari}$ agar proses pengolahan pakan ternak lebih cepat, kualitas pakan lebih baik, biaya pakan ternak ekonomis sehingga kesejahteraan Koptan Harum semakin meningkat.
Limbah yang digunakan untuk pembuatan pakan alternatif ternak entok ini tersedia melimpah di wilayah Gondangrawe, Kecamatan Andong Kabupaten Boyolali. Limbah tersebut meliputi: kulit kacang tanah, tongkol jagung, dan gedebok pisang.

Salah satu metode analisis kimia bahan pakan ternak yang mengacu pada komposisi kimia dan fungsinya disebut analisis proksimat (Rochmah, 2016). Menurut Lokapirnasari et al., (2018) menjelaskan bahwa kulit kacang tanah memiliki 91,76\% bahan kering, 9,49\% abu, 9,27\% protein kasar, 3,38\% lemak kasar, $42,20 \%$ serat kasar, 27,42\% BETN 2662,45 \% Digestible Energy (DE) dan 1811,0716 Kcal/kg Metabolizable Energy (ME). Menurut Abdul Halid \& Mustaring (2019) menyatakan bahwa ternak yang diberikan bahan pakan kulit kacang tanah memiliki Kecernaan Bahan Kering (KBK) 18,08\%; Kecernaan Bahan Organik (KCBO) 16,75\% dan Kecernaan Protein Kasar (KCPK) 18,63 \%.

Tongkol jagung merupakan salah satu limbah yang dapat digunakan untuk membuat pakan ternak. Menurut Yulistiani, et al., (2012) menyatakan bahwa kecernaan bahan kering $(B K)$ secara nyata $(P<0,05)$ meningkat pada tongkol jagung yang diberi perlakuan urea $3 \%$ meningkat sebesar 31\%.Perbedaan pengaruh panjang mutlak, berat mutlak, konversi pakan, dan efisiensi pakan ternak disebabkan perbedaan formulasi pakan tepung tongkol jagung (Novrianto et al., 2019). Menurut Semaun et al., (2016) menyatakan bahwa kandungan serat kasar tongkol jagung tanpa fermentasi (TO) sebesar $31,37 \%$, sedangkan fermentasi tongkol jagung menggunakan Aspergillus niger selama 4 hari $(33,35 \%)$, 8 hari $(31.05 \%)$, dan 12 hari $(32,30 \%)$.

Menurut Labatar (2018) telah meneliti kandungan nutrisi lengkap pada gedebog pisang sebagai pakan alternatif bagi ternak. Pertambahan berat badan ternak setiap hari dipengaruhi pakan fermentasi batang dan kulit pisang pada taraf $20 \%$ dan $30 \%$ dapat menaikkan palatabilitas dan daya cerna ternak sapi, hal ini terbukti nilai $\mathrm{P}<0,05$.

Bagian batang pisang mempunyai kadar air yang sangat tinggi sehingga kadar bahan kering menjadi sangat kecil. sampai mencapai 3,6\%. Hal ini berarti pemberian batang pisang dalam bentuk segar secara tidak langsung memberikan air minum ternak. Kandungan senyawa karbohidrat pada batang pisang cukup baik, terlihat, kandungan serat kasar $21,61 \%$ dan bahan 
ekstrak tanpa nitrogen (BETN) 59,03\% (Devri et al., 2020).

Teknologi fermentasi adalah suatu metode pemanfaatan limbah menjadi produk berguna dan bernilai ekonomi tinggi. Perkembangbiakan Aspergillus niger selama fermentasi akan memecah karbohidrat diikuti pelepasan molekul air dan $\mathrm{CO}_{2}$ (Zulfanita, 2017).

\section{METODE}

\section{Metode Penerapan Ipteks}

Ditinjau dari sisi Iptek, terdapat added value yaitu pemanfaatan teknologi tepat guna untuk mengolah limbah pertanian dan perkebunan sebagai pakan ternak yang murah, dan bergizi. Penerapan mesin pengolah limbah sistem roraty dilaksanakan di Koptan Harum. Keunggulan mesin pengolah limbah pertanian dan perkebunan ini adalah konstruksi yang kuat, kapasitas tinggi $80 \mathrm{~kg} / \mathrm{jam}$, screen dapat diatur sesuai kebutuhan, produksi cepat, dapat digunakan mengolah berbagai jenis limbah basah maupun kering.

\section{Sosialisasi dan pelatihan manajemen usaha}

Pelatihan manajemen usaha yang diterapkan di UKM Koptan Harum adalah sistem manajemen pemasaran modern mengikuti perkembangan jaman saat ini agar pihak kelompok tani dapat memperluas pangsa pasar pakan alternatif ke beberapa kelompok tani lainnya dan wilayah sekitar maupun pangsa pasar yang lebih luas melalui strategi pemasaran yang tepat dan mudah.

Beberapa tahapan untuk pengumpulan data dengan cara wawancara langsung kepada mitra Koptan Harum, terkait penerapan mesin pengolah limbah, dan tanya jawab kepada peserta pelatihan pembuatan pakan alternatif ternak entok. Teknik analisa data dilakukan dengan cara membandingkan kapasitas produksi pembuatan pakan secara tradisional dan mengunakan mesin pengolah limbah. Bidang manajemen usaha dilakukan dengan cara membuat laporan keuangan dari hasil penjualan pakan alternatif, agar dapat diketahui keuntungan Koptan Harum.

\section{HASIL DAN PEMBAHASAN}

Perencanaan mesin pengolah limbah pertanian dan perkebunan perlu identifikasi dan pemilihan komponen yang sesuai kebutuhan perencanaan elemen mesin meliputi beberapa form perhitungan elemen mesin (Sudiar, 2016). Spesifikasi mesin ini adalah

Kapasitas : $80 \mathrm{~kg} / \mathrm{jam}$

Penggerak : Diesel 22 HP

Pisau : baja cold work steel (58-60

hrc)

Bahan : Besi UNP15, Plat eser

Sistem : Rotary

Penggunaan mesin ini dapat menghasilkan pakan ternak entok yang lebih kualitas, ukuran tekstur dapat diatur sesuai kebutuhan, ukuran homogen, kapasitas besar, waktu produksi cepat, dapat dipindahpindah. Namun sedikit kelemahan mesin ini adalah luaran yang berupa serbuk sebagian terbang melalui celah housing blade sehingga menimbulkan polusi.

Mesin pengolah limbah pertanian dan perkebunan yang telah diterapkan pada mitra disajikan pada Gambar 3.
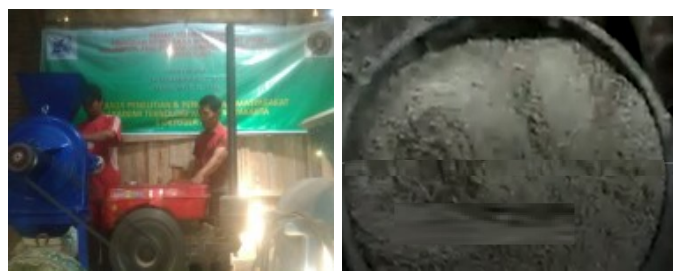

Gambar 3. Pembuatan pakan ternak entok menggunakan mesin pengolah limbah

Berdasarkan Gambar 3, mesin pengolah limbah hasil luaran PKM ini sangat cocok diterapkan Koptan Harum untuk membantu peningkatan kesejahteraan ekonomi peternak entok. Masyarakat sangat antusias dengan bantuan mesin ini, sehingga tidak mengalami kesuiltan lagi untuk membuat pakan alternatif ternak entok.

Selanjutnya limbah yang sudah digiling menjadi serbuk, dicampur dengan Suplemen Organik Cair (SOC) dan dimasukkan ke dalam drum untuk difermentasi selama 1 sampai 2 hari agar pakan lebih lunak dan mudah dicerna oleh ternak entok seperti disajikan pada Gambar 4. Proses fermentasi ini sejalan dengan hasil penelitan yang dilakukan oleh Zulfanita (2017) yang menyatakan bahwa fermentasi adalah proses penguraian senyawa-senyawa organik untuk pengubahan substrat menjadi produk baru oleh mikroba. 


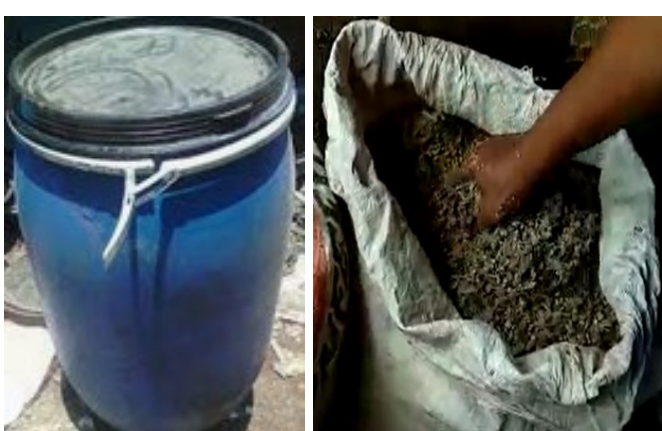

Gambar 4. Proses fermentasi limbah pertanian dan perkebunan

Selanjutnya, pakan yang telah diproduksi diberikan kepada ternak entok. Proses pemberian pakan entok dilakukan secara rutin agar proses pembesaran berhasil dan entok siap dijual seperti disajikan pada Gambar 5.

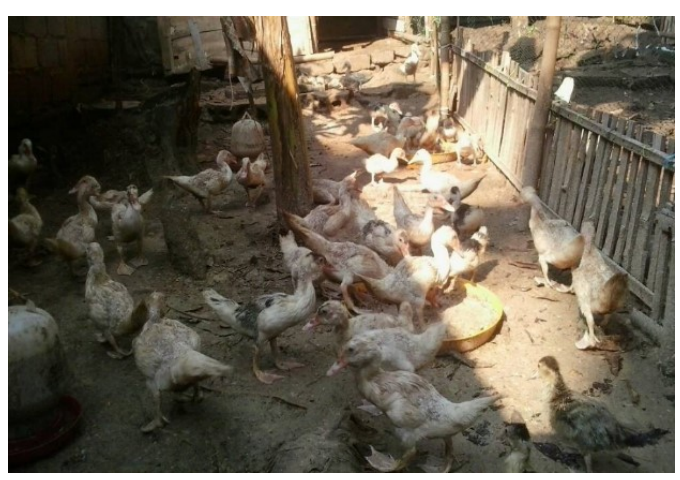

Gambar 5. Proses pembesaran entok

Proses fermentasi sangat berpengaruh pada kualitas pakan alternatif ini karena pakan menjadi lebih lembut/lunak sehingga ternak entok sangat lahap. Hal ini didukung oleh kandungan nutrien pada beberapa limbah seperti kulit kacang tanah yang memiliki Kecernaan Bahan Kering 18,08\%; Kecernaan Bahan Organik 16,75\% dan Kecernaan Protein Kasar 18,63 \% yang dilakukan oleh (Halid dan Mustaring, 2019). Hasil pakan fermentasi tepung tongkol jagung ini juga sejalan dengan penelitian Semaun et al., (2016) yang menyatakan bahwa serat kasar tongkol pada fermentasi tongkol jagung menggunakan Aspergillus niger selama 4 hari (33,35\%). Pakan ternak alternatif hasil kegiatan ini juga sejalan dengan fermentasi yang dilakukan Dharmawan et al., (2019) dengan formulasi campuran dedak padi: tepung jagung: tepung ikan: sayuran dengan perbandingan 4:3:2:1. Ditambahkan100 gram gula pasir dan 20 tutup botol probiotik tiap100 kg pakan.
Adapun hasil fermentasi gedebog pisang dari kegiatan pembuatan pakan alternatif ini didukung oleh penelitian Labatar (2018) yang menjelaskan pertambahan berat badan ternak dipengaruhi pakan fermentasi batang dan kulit pisang pada taraf $20 \%$ dan $30 \%$ yang dapat menaikkan palatabilitas dan daya cerna ternak.

Kegiatan pelatihan manajemen usaha dilakukan dengan anggota Koptan Harum diberikan pengarahan mengenai strategi manajemen bisnis modern dan keuangan yang berguna untuk pengelolaan usaha produksi pakan alternatif ternak entok. Kegiatan pelatihan manajemen usaha ini sejalan dengan kegiatan yang dilakukan Anggarani et al., (2019) yang memberikan workshop manajemen bisnis dan keuangan.

Berdasarkan analisis ekonomi dari perbandingan keuntungan pembuatan pakan menggunakan peralatan tradisional dan setelah mengggunakan mesin untuk pengolah limbah menjadi pakan ternak disajikan pada Tabel 1.

Tabel 1. Perbandingan analisis ekonomi

\begin{tabular}{|c|c|c|c|}
\hline \multirow{2}{*}{\multicolumn{2}{|c|}{$\begin{array}{c}\text { Tradisional } \\
\text { Pengeluaran/100 ekor }\end{array}$}} & \multicolumn{2}{|c|}{ Mesin pengolah limbah } \\
\hline & & \multicolumn{2}{|c|}{ Pengeluaran/100 ekor } \\
\hline Bekatul & 481.800 & Bekatul & 166.000 \\
\hline Konsentrat & 1.775 .000 & Konsentrat & 135.000 \\
\hline Biaya TK & 7.500 .000 & Biaya TK & 3.500 .000 \\
\hline $\mathrm{BR}$ & 1.325 .000 & $\mathrm{SOC}$ & 205.000 \\
\hline Kulit kacang & 17.000 & Kulit kacang & 25.000 \\
\hline Tongkol & 6.000 & Tongkol & 9.000 \\
\hline Gedebog & 0 & Gedebog & 0 \\
\hline \multirow[t]{2}{*}{ DOD } & 500.000 & Fermentasi & 100.000 \\
\hline & & Drum & 250.000 \\
\hline $\begin{array}{l}\text { Total } \\
\text { pengeluaran }\end{array}$ & 11.604 .800 & $\begin{array}{l}\text { Total } \\
\text { pengeluaran }\end{array}$ & 4.390 .000 \\
\hline Pemasukan & 15.000 .000 & Pemasukan & 15.000 .000 \\
\hline $\begin{array}{l}\text { Keuntungan/ } \\
100 \text { ekor }\end{array}$ & 3.395 .200 & $\begin{array}{l}\text { Keuntungan/ } \\
100 \text { ekor }\end{array}$ & 10.610 .000 \\
\hline
\end{tabular}

Berdasarkan Tabel 1 menunjukkan bahwa perbandingan analisis ekonomi dari arus kas pembuatan pakan secara tradisional memiliki keuntungan Rp. 3.395.200/100 ekor. Apabila pembuatan pakan menggunakan mesin pengolah limbah keutungan yang diperoleh sebesar 10.610 .000 atau ada peningkatan keuntungan sebesar $68 \%$.

\section{SIMPULAN DAN SARAN}

\section{Simpulan}

1. Mesin pengolah limbah pertanian dan perkebunan yang diterapkan pada Koptan Harum digunakan untuk memproduksi pakan ternak entok berkapasitas 80 $\mathrm{kg} / \mathrm{jam}$, sistem rotary, penggerak motor 
diesel, pisau: baja cold work steel (60 hrc), bahan: besi UNP 15, pelat eser 15 , besi siku, dan hollow.

2. Berdasarkan hasil aplikasi mesin yang telah diterapkan pada mitra menunjukkan bahwa kapasitas produksi pakan ternak meningkat dari $4 \mathrm{~kg} / \mathrm{jam}$ menjadi 80 $\mathrm{kg} / \mathrm{jam}$.

3. Mesin untuk menggiling gedebog pisang, kulit kacang, tonggol jagung selanjutnya dicampur SOC, dan difermentasi menjadi pakan entok yang ekonomis.

4. Penggunaan mesin pengolah limbah dapat menghemat biaya pakan pabrik sebesar Rp. 7.214.800/100 ekor entok atau terjadi peningkatan keuntungan $68 \%$.

Saran

1. Peningkatan kualitas pakan dapat dilakukan dengan penambahan mesin mixer agar adonan homogen.

2. Partisipasi masyarakat perlu ditingkatkan untuk menggali potensi desa di bidang peternakan, perikanan dan pertanian terpadu.

3. Perlu pengembangan usaha kuliner dari bahan baku entok

\section{DAFTAR PUSTAKA}

Abdul Halid, S., \& Mustaring. (2019). Kajian Bahan Pakan Alternatif (Substitusi) Ruminansia Kecil Sebagai Pakan Komplit. Pembangunan Daerah, 1(1), 29-35.

Anggarani, Irwa A., Purnama, E. R., Dan Raya Sulistyowati. (2019). Kelompok Tani Kecamatan Trawas, Kabupaten Mojokerto ,. 5(1), 1-5.

Devri, A. N., Santoso, H., Dan Muhfahroyin, M. (2020). Manfaat Batang Pisang Dan Ampas Tahu Sebagai Pakan Konsentrat Ternak Sapi. Biolova, 1(1), 30-35. Https://Doi.Org/10.24127/Biolova.V1i1.3 3.

Dharmawan, A. P., Putri, A. A. H., Nurwahyudi, M., \& Afifah, F. (2019). Pelatihan Pembuatan Pakan Fermentasi Dan Aplikasi Probiotik Untuk Itik Petelur Di Desa Kebonsari Sidoarjo. Jurnal Abdi, 5(1), 45. Https://Doi.Org/10.26740/Ja.V5n1.P4549
Labatar, S. C. (2018). Pengaruh Pemberian Batang Dan Kulit Pisang Sebagai Pakan Fermentasi Untuk Ternak Sapi Potong. Triton, 9(1), 31-37.

Lokapirnasari, W. P., Widodo, O. S., 1, S, E. K. (2018). Potensi Bakteri Lactococcus Sp. Dan Lactobacillus Sp. Untuk Peningkatan Kualitas Limbah Kulit Kacang Sebagai Alternatif Bahan Pakan. 10(1), 54-58.

Novrianto, A., Yulfiperius, Y., Andriyeni, A., Nurhabib, A., Dan Supriyono, S. (2019). Pengaruh Pemberian Komposisi Pakan Tepung Tongkol Jagung Yang Berbeda Terhadap Pertumbuhan Ikan Tawes (Puntius Javanicus). Jurnal Agroqua: Media Informasi Agronomi Dan Budidaya Perairan, 17(1), 41.

https://Doi.Org/10.32663/Ja.V17i1.472

Rochmah, K. (2016). Hasil Analisis Proksimat Dari Kulit Kacang Yang Difermentasi Dengan Probiotik Biomc4. Agro Veteriner, 5(1), 28-33.

Semaun, R., dan Abdullah, (2016). Analisis Kandungan Protein Kasar Dan Serat Kasar Tongkol Jagung Sebagai Pakan Ternak Alternatif Dengan Lama Fermentasi Yang Berbeda (Analysis of Protein and Crude Fibre of Corn Cob as Livestock Feed Alternatives with Different of Long Fermentation). Jurnal Galung Tropika, 5(2), 71-79.

Sudiar, A. (2016). Implementasi Dan Perancangan Aplikasi Pada. 8(2), 7378.

Yulistiani, D., W. Puastuti, E. W. D. S. (2012). Pengaruh Berbagai Pengolahan Terhadap Nilai Nutrisi Tongkol Jagung: Komposisi Kimia Dan Kecernaan In Vitro. Jitv, 17, 59-66.

Zulfanita. (2017). Manajemen Kesehatan Ternak Melalui Pemberian Jamu Herbal Fermentasi. 38-44. 